\title{
Characteristics of the NO-NO $2-\mathrm{O}_{3}$ system in different chemical regimes during the MIRAGE-Mex field campaign
}

\author{
Z.-H. Shon ${ }^{1}$, S. Madronich ${ }^{2}$, S.-K. Song ${ }^{3}$, F. M. Flocke ${ }^{2}$, D. J. Knapp ${ }^{2}$, R. S. Anderson ${ }^{2}$, R. E. Shetter ${ }^{2}$, C. A. Cantrell ${ }^{2}$, \\ S. R. Hall ${ }^{2}$, and X. Tie ${ }^{2}$ \\ ${ }^{1}$ Department of Environmental Engineering, Dong-Eui University, 995 Eomgwangno, Busan 614-714, Republic of Korea \\ ${ }^{2}$ Atmospheric Chemistry Division, National Center for Atmospheric Research, P.O. Box 3000 Boulder, CO 80307, USA \\ ${ }^{3}$ Devision of Earth Environmental System, Pusan National University, 30 Jang Jeon Dong, Geum Jeong Gu, Busan 609-735, \\ Republic of Korea
}

Received: 20 December 2007 - Published in Atmos. Chem. Phys. Discuss.: 6 February 2008

Revised: 9 July 2008 - Accepted: 31 October 2008 - Published: 9 December 2008

\begin{abstract}
The NO-NO 2 system was analyzed in different chemical regimes/air masses based on observations of reactive nitrogen species and peroxy radicals made during the intensive field campaign MIRAGE-Mex (4 to 29 March 2006). The air masses were categorized into 5 groups based on combinations of macroscopic observations, geographical location, meteorological parameters, models, and observations of trace gases: boundary layer (labeled as "BL"), biomass burning ("BB"), free troposphere (continental, "FTCO" and marine, "FTMA"), and Tula industrial complex ("TIC"). In general, $\mathrm{NO}_{2} / \mathrm{NO}$ ratios in different air masses are near photostationary state. Analysis of this ratio can be useful for testing current understanding of tropospheric chemistry. The ozone production efficiency (OPE) for the 5 air mass categories ranged from 4.5 (TIC) to 8.5 (FTMA), consistent with photochemical aging of air masses exiting the Mexico City Metropolitan Area.
\end{abstract}

\section{Introduction}

During March of 2006, the Megacities Impact on Regional and Global Environment: Mexico (MIRAGE-Mex) field campaign took place over the Mexico City Metropolitan Area (MCMA) and the surrounding region including the Gulf of Mexico, as part of the MILAGRO Project. This field campaign was designed to examine the chemical and physical transformations of gases and aerosols in the pol-

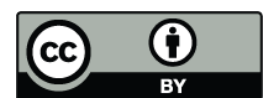

Correspondence to: Z.-H. Shon (zangho@deu.ac.kr) luted outflow from MCMA and to assess the current and future impacts of these exported pollutants on regional and global air quality, ecosystems, and climate. MCMA is a megacity of about 20 million people residing in an area of $1500 \mathrm{~km}^{2}$, surrounded by mountains and at an elevation of $2.2 \mathrm{~km}$ above sea level (a.s.1.). The air quality in MCMA is affected by strong anthropogenic sources of $\mathrm{NO}_{\mathrm{x}}\left(\mathrm{NO}+\mathrm{NO}_{2}\right)$ and volatile organic compounds (VOCs) in conjunction with high solar irradiance facilitating photochemistry (Raga et al., 2001). In the 1990's, hourly averaged ozone concentrations in MCMA exceeded the Mexican national standard of $110 \mathrm{ppbv}$ for much of the year (Raga and Raga, 2000).

As essential ingredients for the formation of $\mathrm{O}_{3}$, the reactive nitrogen species $\left(\mathrm{NO}_{\mathrm{x}}\right)$ are emitted to the atmosphere mainly in the form of NO from road traffic (Soltic and Weilenmann, 2003). $\mathrm{NO}$ and $\mathrm{NO}_{2}$ are interconverted rapidly through the following reactions:

$\mathrm{NO}+\mathrm{O}_{3} \rightarrow \mathrm{NO}_{2}+\mathrm{O}_{2}$

$\mathrm{NO}_{2}+h v(\lambda<420 \mathrm{~nm})\left(+\mathrm{O}_{2}\right) \rightarrow \mathrm{NO}+\mathrm{O}_{3}$

$\mathrm{NO}+\mathrm{HO}_{2} \rightarrow \mathrm{NO}_{2}+\mathrm{OH}$

$\mathrm{NO}+\mathrm{RO}_{2} \rightarrow \mathrm{NO}_{2}+\mathrm{RO}$

$\mathrm{NO}+\mathrm{XO} \rightarrow \mathrm{NO}_{2}+\mathrm{X}$

where $\mathrm{RO}_{2}$ is any organic peroxy radical including $\mathrm{CH}_{3} \mathrm{O}_{2}$, $\mathrm{RO}$ is the corresponding alkoxy radical, and $\mathrm{XO}$ is any unknown radical that may convert $\mathrm{NO}$ to $\mathrm{NO}_{2}$. The $\mathrm{NO}_{2} / \mathrm{NO}$ ratio can be formulated as:

$\frac{\left[\mathrm{NO}_{2}\right]}{[\mathrm{NO}]}=\frac{\left(k_{1}\left[\mathrm{O}_{3}\right]+k_{3}\left[\mathrm{HO}_{2}\right]+k_{4}\left[\mathrm{RO}_{2}\right]+k_{5}[\mathrm{XO}]\right)}{J_{2}}$

Published by Copernicus Publications on behalf of the European Geosciences Union. 
where $k_{1}, k_{3}, k_{4}$, and $k_{5}$ are reaction rate constants for the reactions $\mathrm{R} 1, \mathrm{R} 3, \mathrm{R} 4$, and $\mathrm{R} 5$, respectively and $J_{2}$ is the photolysis frequency of $\mathrm{NO}_{2}$. Previous studies investigating the $\mathrm{NO}-\mathrm{NO}_{2}$ cyclic system were conducted in urban and remote areas utilizing observations of $\mathrm{O}_{3}(\mathrm{R} 1)$ and/or peroxy radicals (R3-R4) (Cantrell et al., 1997; Crawford et al., 1996 and references therein). They found that model-predicted peroxy radicals were often less than those required to explain the observed $\mathrm{NO}_{2} / \mathrm{NO}$ ratio, resulting in model-predicted $\mathrm{NO}_{2}$ levels that were somewhat lower than observations. For example, comparison between observations and predictions in several field campaigns (CITE-3, ABLE-3B, CITE-2, and TRACE-A) typically showed that $\left[\mathrm{NO}_{2}\right]_{\text {obs }} /\left[\mathrm{NO}_{2}\right]_{\text {calc }}$ ranges from 1.3 to 1.6 with a maximum of up to 3.4 in PEM-West A (Crawford et al., 1996). In contrast, Ridley et al. (1992) found good agreement between model peroxy radicals and those estimated from the $\mathrm{NO}_{2} / \mathrm{NO}$ ratio. Meanwhile, the potential role of iodine chemistry on the $\mathrm{NO}_{2} / \mathrm{NO}$ and $\mathrm{HO}_{2} / \mathrm{OH}$ ratios has been suggested based on field, model, and kinetic studies (Chameides and Davis, 1980; Davis et al., 1996; Knight and Crowley, 2001; Kanaya et al., 2002, 2007). Since both hydroperoxyl and organic peroxy radicals were measured during the MIRAGE-Mex campaign, the photostationary state (PSS) of the NO- $\mathrm{NO}_{2}$ system can be assessed based on field observations in this study without model estimates.

To assess the impact of MCMA emissions on $\mathrm{O}_{3}$ and its precursors on regional and hemispheric scales, it is important to evaluate the loss and transformation processes of reactive nitrogen species $\left(\mathrm{NO}_{\mathrm{x}}\right.$ to $\mathrm{NO}_{\mathrm{y}}$, which is total reactive nitrogen oxides) in the course of transport of urban or industrial plumes. The emitted $\mathrm{NO}_{\mathrm{x}}$ can be oxidized in the atmosphere by $\mathrm{OH}$, forming $\mathrm{HNO}_{3}$ which is subject to removal from the air mass through dry and wet deposition. The average lifetime of $\mathrm{NO}_{\mathrm{y}}$ in urban, industrial (Nunnermacker et al., 2000) or continental outflow plumes (Takegawa et al., 2004) ranges from 0.25 to several days; whereas that of $\mathrm{NO}_{\mathrm{x}}$ in each environment is slightly shorter (less than 0.25 day in the former environment with longer lifetime in the latter environment e.g., 1-2 days).

In this study, we analyzed the NO- $\mathrm{NO}_{2}$ cyclic system in different chemical regimes/air masses based on observations of reactive nitrogen species and peroxy radicals. The analysis of PSS allows us to assess the current understanding of tropospheric $\mathrm{NO}_{\mathrm{x}}$ chemistry including the potential for yet-unidentified chemical reactions. We also examined the $\mathrm{NO}_{\mathrm{x}} / \mathrm{NO}_{\mathrm{y}}$ ratios and ozone production efficiencies (OPEs) of the polluted outflow from MCMA, providing some insight on the photochemical aging processes in various chemical regimes.

\section{Observational data}

The intensive field campaign of MIRAGE-Mex was carried out from 4 March to 29 March 2006, involving the
NSF/NCAR C-130 aircraft, ground-based measurements, and satellite observations. This campaign made numerous physico-chemical measurements such as reactive nitrogen species, oxidized sulfur species, oxygenated VOCs, aerosols, peroxy radicals, and so on. It also included the measurements of actinic flux and atmospheric photolysis frequencies such as $J\left(\mathrm{O}_{3}\right), J\left(\mathrm{NO}_{2}\right), J\left(\mathrm{HNO}_{2}\right)$, etc., with 5s time resolution (Shetter et al., 2003). These measurements allow for the PSS analysis of the NO- $\mathrm{NO}_{2}$ system and are also used for air mass classification. The full details of measurements taken from C-130 during the field campaign can be found elsewhere (http://mirage-mex.acd. ucar.edu/Measurements/C130/index.shtml). Reactive nitrogen species, including $\mathrm{NO}, \mathrm{NO}_{2}, \mathrm{NO}_{\mathrm{y}}$, and $\mathrm{O}_{3}$ were measured at $1 \mathrm{~Hz}$ with a chemiluminescence technique (Weinheimer et al., 1998). For $\mathrm{NO}, \mathrm{NO}_{2}$, and $\mathrm{NO}_{\mathrm{y}}$, the precision of these measurements is near $15 \mathrm{pptv}$ and the overall estimated uncertainties are $\pm(15+7 \%$ of the mixing ratio $)$ pptv for $\mathrm{NO}, \pm\left(15+10 \%\right.$ of the mixing ratio) pptv for $\mathrm{NO}_{2}$, and $\pm\left(15+15 \%\right.$ of mixing ratio) pptv for $\mathrm{NO}_{\mathrm{y}}$. As one of key measurements for the analysis of $\mathrm{NO}-\mathrm{NO}_{2}$ PSS (Eq. 1), peroxy radicals $\left(\mathrm{HO}_{2}+\mathrm{RO}_{2}\right)$ were measured with the fourchannel CIMS at 3-s time interval (Cantrell et al., 2003). The overall estimated uncertainty of the peroxy radical measurement is $\pm(2.5+17.5 \%$ of the mixing ratio $)$ pptv. In this study, 1-min merged data sets were used, which were created to align chemical species measured with varying time resolution and are available on MILAGRO/INTEX-B/IMPEX archive (ftp://ftp-air.larc.nasa.gov).

Twelve C-130 missions were flown during the campaign, covering the altitude from the surface to about $7 \mathrm{~km}$. Most of the flights sampled air over the MCMA basin and central Mexico, and several of the flights extended over the Gulf of Mexico to sample continental outflow from the MCMA. Figure 1 shows $\mathrm{C}-130$ flight tracks during the field campaign. In the temporal coverage, data sets used in this study were measured predominantly during daytime and (in smaller number) near sunrise and sunset. For this analysis, data were limited to solar zenith angles (SZA) less than $85^{\circ}$. The data of flight 6 were excluded in the PSS analysis due to malfunction of the ozone instrument.

\section{Results and discussion}

\subsection{Air mass category}

In order to analyze the $\mathrm{NO}-\mathrm{NO}_{2}$ cycling in different chemical regimes, the air masses were categorized into 5 groups: boundary layer (BL), free troposphere (continental, FTCO and marine, FTMA), biomass burning (BB), and Tula Industrial Complex (TIC). The air mass characterization was determined based on combinations of macroscopic observations, geographical location, meteorological parameters (temperature and relative humidity, etc.), models (Weather Research 


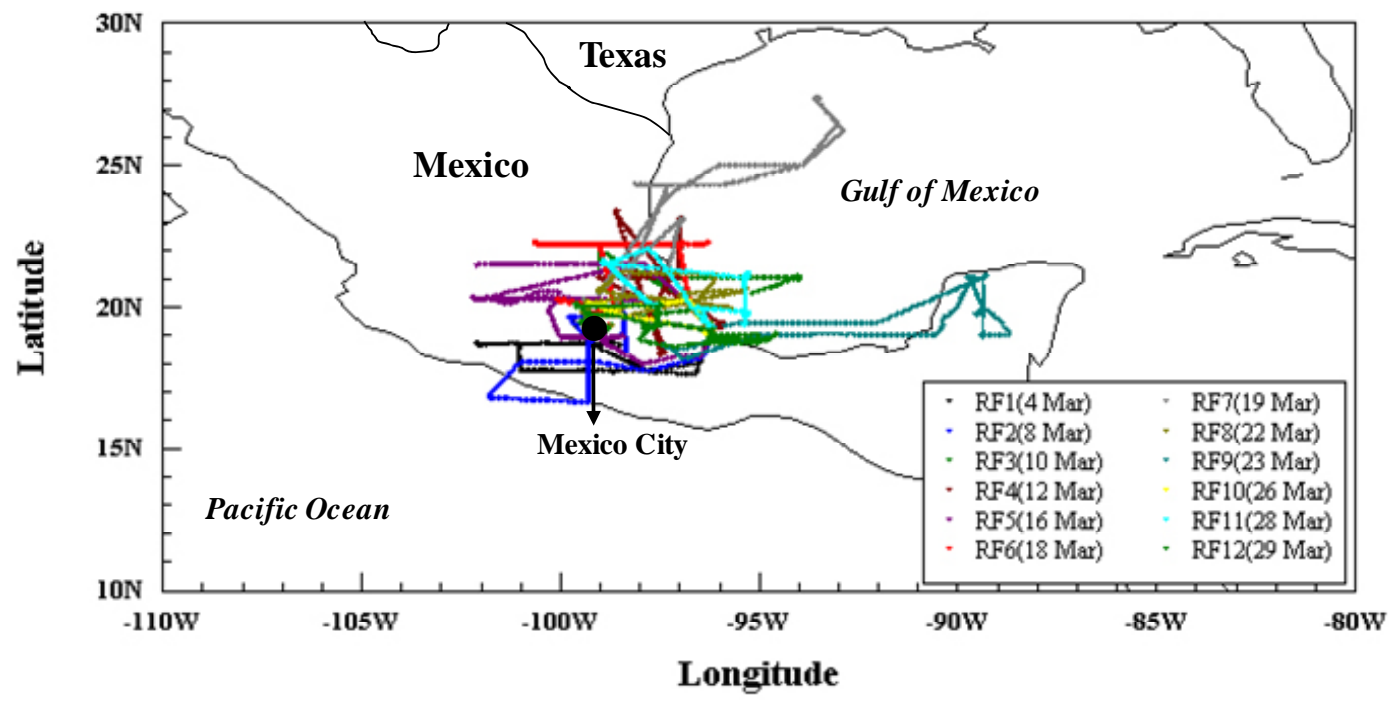

Fig. 1. C-130 flight tracks during the MIRAGE-Mex field campaign (March 2006).

Table 1. Criteria for the determination of air mass category.

\begin{tabular}{llllllll}
\hline & $\begin{array}{l}\text { Altitude } \\
(\mathrm{km})\end{array}$ & $\begin{array}{l}\text { Geographical } \\
\text { Location }\end{array}$ & $\begin{array}{l}\mathrm{HCN} \\
(\mathrm{pptv})\end{array}$ & $\begin{array}{l}\mathrm{C}_{2} \mathrm{Cl}_{4} \\
(\mathrm{pptv})\end{array}$ & $\begin{array}{l}\mathrm{CO} \\
(\mathrm{ppbv})\end{array}$ & $\begin{array}{l}\mathrm{NO}_{\mathrm{x}} \\
(\mathrm{ppbv})\end{array}$ & $\begin{array}{l}\mathrm{SO}_{2} \\
(\mathrm{ppbv})\end{array}$ \\
\hline $\mathrm{BL}$ & $0.9(\mathrm{~F} 4)-1.2(\mathrm{~F} 1)^{*}$ & & & & \\
FTCO & $>\{0.9(\mathrm{~F} 4)-1.2(\mathrm{~F} 1)\}$ & Continent & & & & \\
FTMA & $>\{0.9(\mathrm{~F} 4)-1.2(\mathrm{~F} 1)\}$ & Marine & & & & \\
$\mathrm{BB}$ & & & $\geq 189$ & $\geq 0.3$ & $\geq 81$ & & \\
TIC & & $\begin{array}{l}\text { around Tula } \\
\text { Refinery }\end{array}$ & & $\geq 67$ & $\geq 0.05$ & $\geq 0.15$ \\
& & & & & & \\
\hline
\end{tabular}

* The number represents the range of minimum and maximum values for median values of BL heights of each flight (F1 to F12).

and Forecasting (WRF) with Chemistry, WRF-Chem, Tie et al., 2007 and references therein), and observations of trace gases (Table 1). For instance, the category for the BL air masses was determined based on meteorological parameters and WRF-Chem and those for FTCO and FTMA were based on geographical locations of airborne sampling. In addition, that for the BB was determined based on macroscopic observation (i.e., fire in nearby mountains) and chemical observations (i.e., significant increase in concentration levels compared to previous flight legs) such as hydrogen cyanide ( $\mathrm{HCN})$, perchlorethene $\left(\mathrm{C}_{2} \mathrm{Cl}_{4}\right)$, and $\mathrm{CO}$ (Gregory et al., 1996; $\mathrm{Li}$ et al., 2000), while that for TIC was based on the concentration levels of $\mathrm{CO}, \mathrm{NO}_{\mathrm{x}}$, and $\mathrm{SO}_{2}$. A statistical summary of the concentrations observed in the different air mass categories is given in Table 2. The mean concentration of HCN for the BB (measured on 4, 22, and 23 March) is factors of 1.5 (TIC), 1.8 (BL), 2.4 (FTMA), and 2.9 (FTCO) higher than those for other air mass categories. The mean concentration of $\mathrm{SO}_{2}$ for the TIC (measured on 10, 19, and 22 March) is higher than those for other air mass categories by factors ranging from 4.7 to 16 .

High levels of $\mathrm{NO}_{\mathrm{x}}$ and $\mathrm{NO}_{\mathrm{y}}$ within the megacity result from enhanced local emission sources such as combustion. Thus, $\mathrm{NO}_{\mathrm{x}}$ can be a measure of anthropogenic impact at the sampling position. In addition, the ratio of $\mathrm{NO}_{\mathrm{x}}$ to $\mathrm{NO}_{\mathrm{y}}$ can be valuable for understanding the extent of chemical processing and as an indicator for photochemical age (Carroll et al., 1992), in spite of several limitations including the assumptions of no physicochemical loss (only dilution of $\mathrm{NO}_{\mathrm{y}}$ ), no chemical transformation from $\mathrm{NO}_{\mathrm{y}}$ to $\mathrm{NO}_{\mathrm{x}}$ (e.g., thermal decomposition of PAN), constant emission sources, and constant background concentration. In this field study, the mean $\mathrm{NO}_{\mathrm{x}} / \mathrm{NO}_{\mathrm{y}}$ ratio varied from 0.15 (FTMA) to 0.38 (BL), depending on air mass category (Table 2). The higher mean ratios $(0.21-0.38)$ for BL, BB, and TIC (Table 2) indicate less aged air than those $(0.15-0.19)$ for FTCO and FTMA 

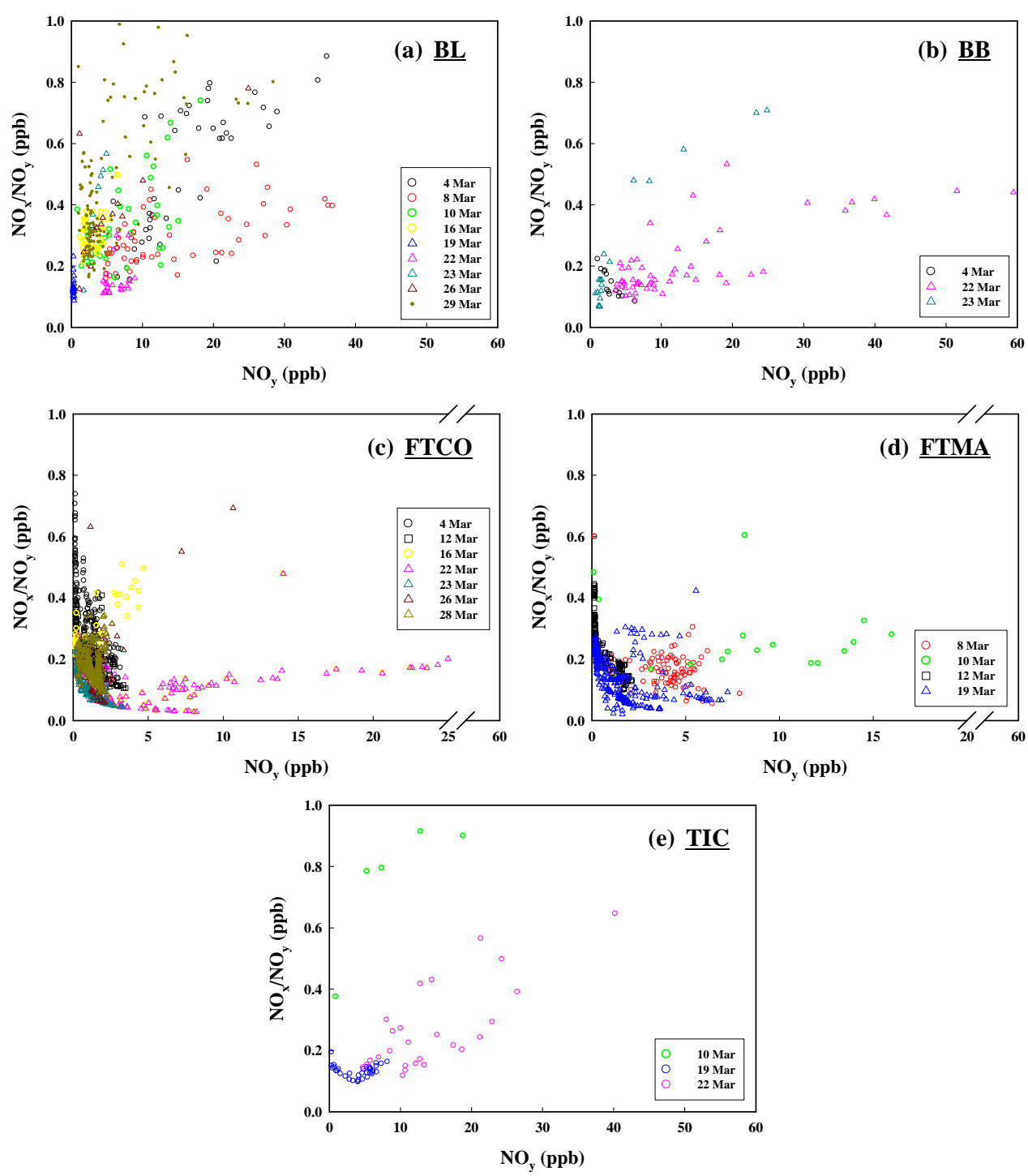

Fig. 2. Relation between $\mathrm{NO}_{\mathrm{x}} / \mathrm{NO}_{\mathrm{y}}$ and $\mathrm{NO}_{\mathrm{y}}$ for 5 air mass categories (BL a, BB b, FTCO c, FTMA d, and TIC e).

(Table 2). The slightly lower ratios for FTCO and FTMA indicated more photochemical aging.

The variation of $\mathrm{NO}_{\mathrm{x}} / \mathrm{NO}_{\mathrm{y}}$ ratios with concentration level of $\mathrm{NO}_{\mathrm{y}}$ for each air mass is shown in Fig. 2, which can provide information on the characteristics of different air masses. In general, some positive correlation might be expected because high $\mathrm{NO}_{\mathrm{y}}$ may indicate proximity to sources and high $\mathrm{NO}_{\mathrm{x}} / \mathrm{NO}_{\mathrm{y}}$ ratios indicate freshly emitted pollution before much photochemical processing has occurred. For the BL, the ratios significantly varied from 0.1 to 1 with high $\mathrm{NO}_{\mathrm{y}}$ concentration, indicating a range of photochemical ages. In contrast, the ratios for the BB were concentrated at 0.2 , with only a few values above 0.4 . In general, the air masses for FTCO and FTMA appear to have similarity in the ratio patterns, with relatively low ratios (aged air) for $\mathrm{NO}_{\mathrm{y}}$ levels larger than a few ppbv, indicating that the pol- luted plumes have aged substantially. However, the ratios for FTCO at low $\mathrm{NO}_{\mathrm{y}}$ levels (less than a few ppbv) showed larger variation than the ratios for FTMA and those at high $\mathrm{NO}_{\mathrm{y}}$ levels (greater than a few ppbv) were also somewhat lower. Note that the high ratios at low absolute $\mathrm{NO}_{\mathrm{y}}$ were not affected by the low $\mathrm{NO}_{\mathrm{y}}$ levels which are significantly higher than $\mathrm{NO}_{\mathrm{y}}$ detection limit. The ratios for the TIC correlate fairly well with $\mathrm{NO}_{\mathrm{y}}$, as might be expected from dilution and aging of the plume from this fairly localized source.

The $\mathrm{NO}_{\mathrm{x}} / \mathrm{NO}_{\mathrm{y}}$ ratios during MIRAGE-Mex were significantly higher than those (0.02-0.2) in continental outflow from East Asia during TRACE-P (Koike et al., 2003). However, the higher ratio $(0.38)$ for $\mathrm{BL}$ was comparable to those in the near 2 day aged Asian outflow plume measured during the PEACE-A campaign (Takegawa et al., 2004). Our ratios (0.15-0.19) for the FTCO and FTMA were similar to 
Table 2. A statistical summary of reactive nitrogen compounds, major air pollutants, and peroxy radicals with air mass categories measured during the MIRAGE field campaign.

\begin{tabular}{|c|c|c|c|c|c|c|c|c|c|c|c|c|c|}
\hline $\begin{array}{l}\text { Air mass } \\
\text { category* }\end{array}$ & NO (ppbv) & $\mathrm{NO}_{2}$ (ppbv) & $\mathrm{NO}_{\mathrm{x}}(\mathrm{ppbv})$ & $\mathrm{NO}_{\mathrm{y}}(\mathrm{ppbv})$ & $\mathrm{CO}$ (ppbv) & $\mathrm{O}_{3}$ (ppbv) & $\mathrm{SO}_{2}$ (ppbv) & $\mathrm{HO}_{2}$ (pptv) & $\mathrm{RO}_{2}$ (pptv) & $\mathrm{HCN}$ (pptv) & $\mathrm{C}_{2} \mathrm{Cl}_{4}$ (pptv) & $\mathrm{NO}_{\mathrm{x}} / \mathrm{NO}_{\mathrm{y}}$ & $\mathrm{NO}_{2} / \mathrm{NO}^{\mathrm{e}}$ \\
\hline \multirow[t]{4}{*}{ BL } & $0.7 \pm 1.1^{\mathrm{a}}$ & $3.0 \pm 4.2$ & $3.7 \pm 5.1$ & $7.8 \pm 7.4$ & $249 \pm 110$ & $79 \pm 25$ & $4.7 \pm 17.9$ & $77 \pm 49$ & $54 \pm 48$ & $529 \pm 225$ & $8.6 \pm 9.5$ & $0.38 \pm 0.22$ & $4.4 \pm 2.2$ \\
\hline & $0.27^{\mathrm{b}}$ & 1 & 1.3 & 4.9 & 223 & 76 & 1.9 & 55 & 35 & 475 & 4.0 & 0.31 & 4.1 \\
\hline & $0.01-7.8^{\mathrm{c}}$ & $0.07-27$ & $0.09-32$ & $0.9-37$ & $111-688$ & $32-153$ & $0.2-207$ & $12-246$ & $0.8-241$ & $96-1291$ & $0.5-31$ & $0.09-1.47$ & $1.5-17$ \\
\hline & $387^{\mathrm{d}}$ & 387 & 387 & 375 & 170 & 396 & 278 & 267 & 255 & 291 & 126 & 375 & 387 \\
\hline \multirow[t]{4}{*}{ BB } & $0.5 \pm 0.8$ & $2.5 \pm 4.6$ & $3.1 \pm 5.3$ & $10.2 \pm 11.5$ & $278 \pm 184$ & $74 \pm 30$ & $2.7 \pm 2.1$ & $58 \pm 26$ & $159 \pm 71$ & $965 \pm 761$ & $4.2 \pm 7.5$ & $0.21 \pm 0.14$ & $4.1 \pm 1.5$ \\
\hline & 0.2 & 0.7 & 0.9 & 6.3 & 225 & 72 & 2 & 59 & 158 & 905 & 0.9 & 0.15 & 3.7 \\
\hline & $0.02-4.0$ & $0.06-23$ & $0.08-26$ & $0.7-59$ & $81-937$ & $29-151$ & $0.2-9.7$ & $12-106$ & $58-362$ & $189-5952$ & $0.3-32$ & $0.07-0.71$ & $1.7-10$ \\
\hline & 88 & 88 & 88 & 86 & 58 & 90 & 60 & 24 & 30 & 65 & 30 & 86 & 88 \\
\hline \multirow[t]{4}{*}{ FTCO } & $0.05 \pm 0.09$ & $0.2 \pm 0.4$ & $0.3 \pm 0.5$ & $1.7 \pm 2.6$ & $128 \pm 41$ & $51 \pm 14$ & $2.0 \pm 6.8$ & $45 \pm 33$ & $43 \pm 38$ & $338 \pm 153$ & $1.3 \pm 3.9$ & $0.19 \pm 0.12$ & $\begin{array}{l}4.2 \pm 4.3 \\
(3.7 \pm 4.0)\end{array}$ \\
\hline & 0.03 & 0.1 & 0.2 & 1.3 & 119 & 50 & 0.68 & 40 & 29 & 318 & 0.6 & 0.16 & 3.1 \\
\hline & $0-1.7$ & $0.01-5.7$ & $0.03-7.4$ & $0.06-25$ & $69-424$ & $0.4-144$ & $0-120$ & $0.01-353$ & $0.02-194$ & $107-1093$ & $0.2-35$ & $0.03-1.13$ & $0.5-32$ \\
\hline & 1125 & 1185 & 1132 & 1057 & 636 & 1246 & 687 & 778 & 564 & 645 & 252 & 839 & 747 \\
\hline \multirow[t]{4}{*}{ FTMA } & $0.06 \pm 0.1$ & $0.3 \pm 0.4$ & $0.3 \pm 0.6$ & $2.0 \pm 2.2$ & $123 \pm 64$ & $57 \pm 17$ & $1.4 \pm 1.6$ & $30 \pm 20$ & $22 \pm 17$ & $395 \pm 249$ & $2.2 \pm 4.0$ & $0.15 \pm 0.08$ & $\begin{array}{l}6.4 \pm 9.6 \\
(3.6 \pm 8.7)\end{array}$ \\
\hline & 0.03 & 0.1 & 0.1 & 1.4 & 112 & 57 & 0.93 & 29 & 21 & 369 & 0.9 & 0.14 & 3.3 \\
\hline & $0-1.9$ & $0.02-4.2$ & $0.03-4.9$ & $0.1-16$ & $60-416$ & $29-129$ & $0-10.0$ & $0.1-129$ & $0.3-190$ & $43-1750$ & $0.2-22$ & $0.02-0.60$ & $0.9-93$ \\
\hline & 561 & 563 & 561 & 519 & 351 & 595 & 375 & 237 & 206 & 357 & 122 & 390 & 401 \\
\hline \multirow[t]{4}{*}{ TIC } & $0.7 \pm 1.3$ & $2.0 \pm 3.1$ & $2.6 \pm 4.4$ & $8.5 \pm 7.4$ & $186 \pm 81$ & $72 \pm 19$ & $22.3 \pm 40.4$ & $12 \pm 4$ & $101 \pm 42$ & $651 \pm 372$ & $6.7 \pm 10$ & $0.23 \pm 0.19$ & $3.3 \pm 1.0$ \\
\hline & 0.2 & 0.6 & 0.8 & 6 & 192 & 74 & 9.4 & 13 & 108 & 576 & 2.4 & 0.15 & 3.4 \\
\hline & $0.02-7.4$ & $0.03-19$ & $0.05-26$ & $0.3-40$ & $67-418$ & $40-120$ & $0.15-235$ & $8-18$ & $10-168$ & $104-2100$ & $0.2-36$ & $0.10-0.91$ & $1.5-7.3$ \\
\hline & 69 & 69 & 69 & 67 & 59 & 70 & 43 & 5 & 30 & 47 & 23 & 67 & 69 \\
\hline
\end{tabular}

${ }^{\mathrm{a}}$ Mean $\pm 1 \sigma ;{ }^{\mathrm{b}}$ Median; ${ }^{\mathrm{c}}$ Min.-Max.; ${ }^{\mathrm{d}}$ Number of data; ${ }^{\mathrm{e}}$ The numbers in parenthesis are Mean $\pm 1 \sigma$ calculated with the data set corresponding to $\mathrm{SZA} \leq 85^{\circ}$.

* The category for the BL air masses was determined based on meteorological parameters and WRF-Chem; those for FTCO and FTMA based on geographical locations of airborne sampling; that for the $\mathrm{BB}$ based on hydrogen cyanide $(\mathrm{HCN})$, perchlorethene $\left(\mathrm{C}_{2} \mathrm{Cl} \mathrm{Cl}_{4}\right)$, and $\mathrm{CO}_{\text {; }}$ and that for TIC based on the concentration levels of $\mathrm{CO}, \mathrm{NO}_{\mathrm{x}}$, and $\mathrm{SO}_{2}$.

the ratios (0.13-0.15) for marine air during PEM-Tropics B (Maloney et al., 2001).

The absolute magnitude of chemical observations was also different with air mass categories. For instance, for the BB, $\mathrm{O}_{3}$ and $\mathrm{NO}_{\mathrm{x}}$ concentrations were relatively higher with mean levels of 74 and $3.1 \mathrm{ppbv}$, respectively, higher than those for TIC, but less than those for the BL (79 and $3.7 \mathrm{ppbv}$, respectively) (Table 2). Mean concentrations of $\mathrm{NO}$ and $\mathrm{NO}_{2}$ for the $\mathrm{BB}$ were 0.5 and $2.5 \mathrm{ppbv}$ respectively. Except for the $\mathrm{BL}$, the mean $\mathrm{NO}_{2}$ level for the $\mathrm{BB}$ was higher than those in other air mass categories by at least a factor of 1.3 and as much as a factor of 13 for the FTCO. For FTCO, the mixing ratios of air pollutants such as $\mathrm{O}_{3}$ and $\mathrm{NO}_{\mathrm{x}}$ were low in comparison to other air mass categories, with mean values of 51 and 0.3 ppbv. The relatively high $\mathrm{NO}_{\mathrm{x}}$ levels for the $\mathrm{BB}$ are likely to be affected by outflow from MCMA. $\mathrm{NO}_{\mathrm{x}}$ enrichment was also reported in the forest fire emissions near MCMA during the MIRAGE-Mex campaign on a different airborne platform (Twin Otter), ascribed to the deposition of nitrogen-containing pollutants in the outflow from the MC urban area (Yokelson et al., 2007). The concentrations of peroxy radicals, $\mathrm{HO}_{2}$ and $\mathrm{RO}_{2}$ for the $\mathrm{BB}$ were 58 and 159 pptv, respectively, which were factors of 1.3 to 4.8 (except for the $\mathrm{BL}$ ) and 1.6 to 7.2 higher than those in other air mass categories, respectively. TIC also showed significantly high $\mathrm{RO}_{2}$ concentrations (approximately $100 \mathrm{pptv}$ ).

\subsection{Photostationary state analysis of $\mathrm{NO}-\mathrm{NO}_{2}$ system}

The PSS of NO- $\mathrm{NO}_{2}$ systems with different air mass categories is shown in Fig. 3 and Table 3. The former shows the linear regression between $\mathrm{NO}_{2} / \mathrm{NO}$ and $\left\{k_{1}\left[\mathrm{O}_{3}\right]+k_{3}\left[\mathrm{HO}_{2}\right]+\right.$ $\left.k_{4}\left[\mathrm{RO}_{2}\right]\right\} / J\left(\mathrm{NO}_{2}\right)$ and the latter shows the statistical summary of the PSS parameter $(\phi)$. The mean $\phi$ values for different air masses are un-weighted averages, in other words each individual $\phi$ value is considered with equal weight. The PSS analysis for the air mass types of BB and TIC was excluded due to the limited number of data $(n=8$ for $\mathrm{BB}$ and 

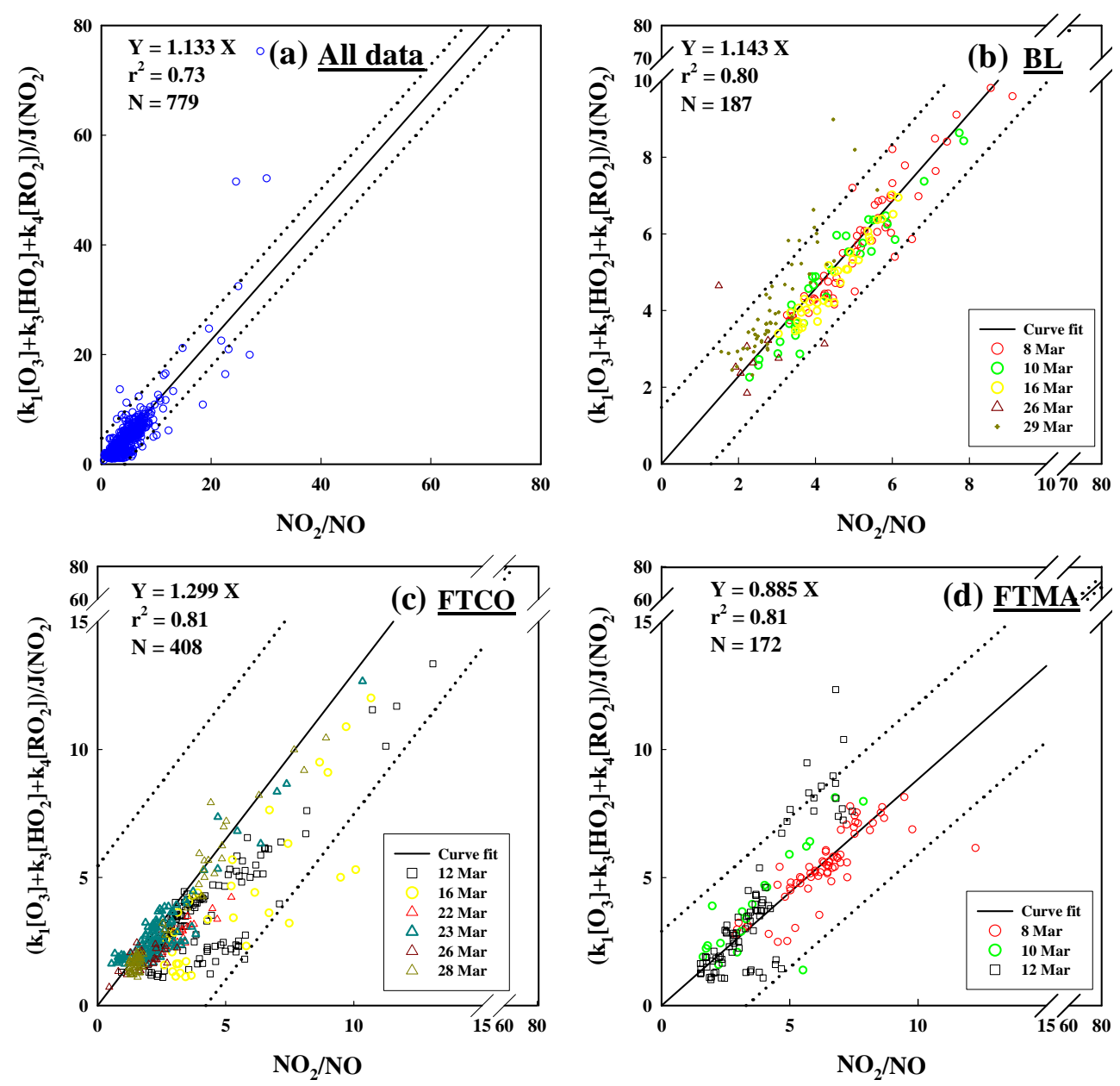

Fig. 3. Photostationary state analysis for the NO- $\mathrm{NO}_{2}$ system during the MIRAGE-Mex field campaign (4 March to 29 March 2006 ) for different air mass categories (all a, BL b, FTCO c, and FTMA d). The photostationary parameter $\phi$ is the slope of these plots. The upper and lower (dotted) lines represent prediction intervals in $95 \%$ confidence level.

Table 3. Statistical summary of the PSS parameter $(\phi)$ and linear regression between $\mathrm{NO}_{2} / \mathrm{NO}$ and $\left\{k_{1}\left[\mathrm{O}_{3}\right]+k_{3}\left[\mathrm{HO}_{2}\right]+k_{4}\left[\mathrm{RO}_{2}\right]\right\} / J\left(\mathrm{NO}_{2}\right)$.

\begin{tabular}{lllllllll}
\hline Air mass category & Slope $^{\mathrm{a}}$ & Slope SE $^{\mathrm{b}}$ & $\mathrm{S}^{\mathrm{c}}$ & $\mathrm{T}_{\text {-value }}$ & $\mathrm{P}_{\text {-value }}$ & $\Delta \phi / \phi(\%)$ & $\phi($ mean $\pm 1 \sigma)$ & $\phi$ (median) \\
\hline BL & 1.14 & 0.012 & 0.75 & 91.97 & 0 & 21 & $1.19 \pm 0.24$ & 1.14 \\
FTCO & 1.30 & 0.029 & 2.79 & 45.50 & 0 & 22 & $1.06 \pm 0.37$ & 1.04 \\
FTMA & 0.89 & 0.018 & 1.48 & 50.18 & 0 & 21 & $0.93 \pm 0.27$ & 0.92 \\
All & 1.13 & 0.017 & 2.42 & 66.75 & 0 & - & $1.08 \pm 0.37$ & 1.06 \\
\hline
\end{tabular}

Values were calculated from the data subset with $\mathrm{SZA} \leq 85^{\circ}$.

${ }^{a}$ Slope of the best-fit line in the Fig. $1 .{ }^{b}$ Standard error of slope. ${ }^{c}$ Square root of mean squared error. 

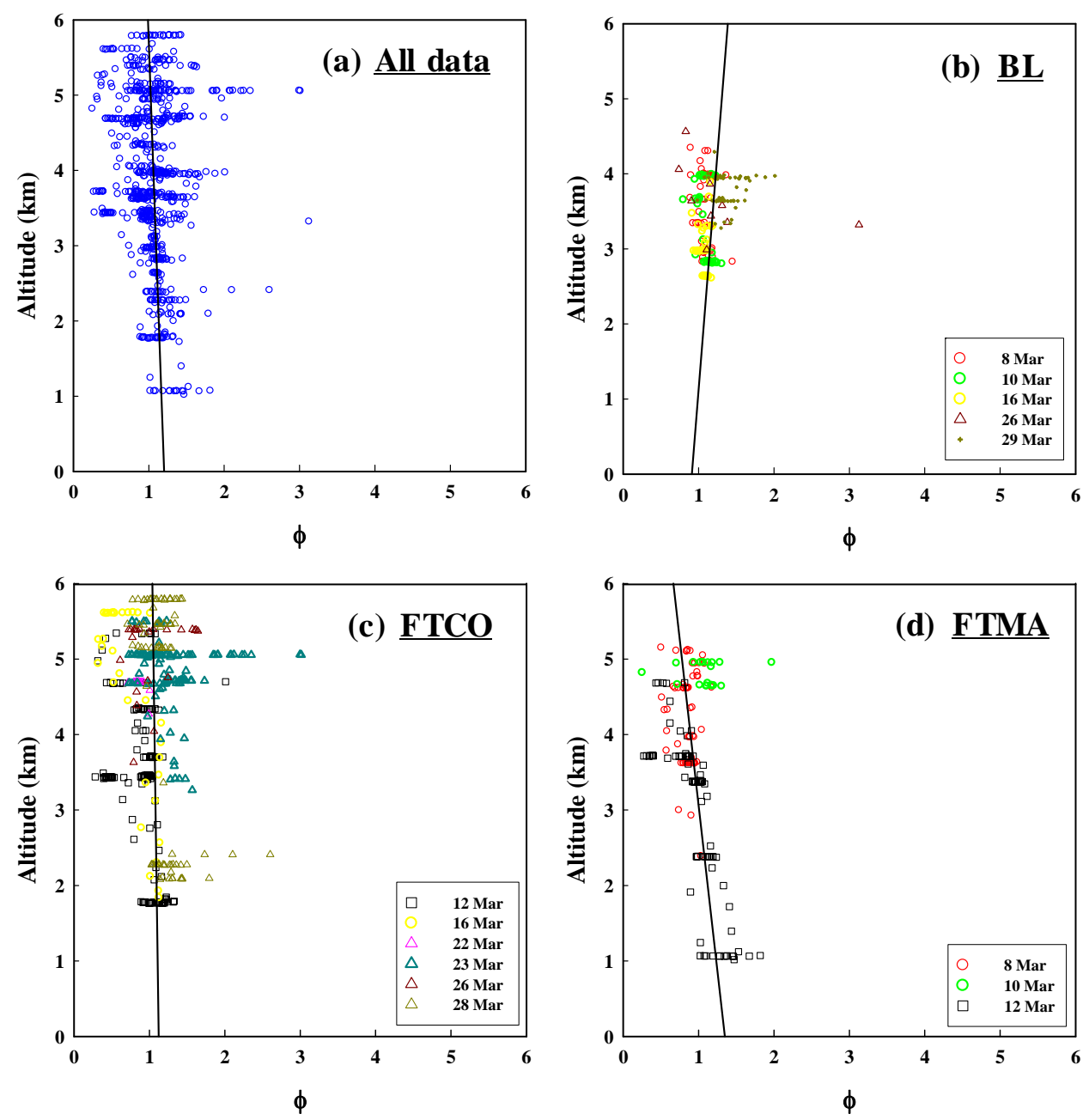

Fig. 4. Vertical profile of the PSS parameter $(\phi)$ for 3 air mass categories (all a, BL b, FTCO c, and FTMA d).

$n=4$ for TIC). The PSS parameter $(\phi)$ is defined as follows:

$\phi=\frac{\left\{k_{1}\left[\mathrm{O}_{3}\right]+k_{3}\left[\mathrm{HO}_{2}\right]+k_{4}\left[\mathrm{RO}_{2}\right]\right\} / J_{2}}{\left[\mathrm{NO}_{2}\right] /[\mathrm{NO}]}$

In Eq. (2), the reaction rate constants $\left(k_{1}, k_{3}\right.$, and $\left.k_{4}\right)$ are taken from Sander et al. (2002) and $k_{4}$ is the coefficient corresponding to the reaction between $\mathrm{NO}$ with $\mathrm{CH}_{3} \mathrm{O}_{2}$. All rate coefficients were adjusted for the temperatures measured during the flights. If Reactions (1-4) represent adequately the $\mathrm{NO}-\mathrm{NO}_{2}$ partitioning, the calculated value of $\phi$ (or the slope of Fig. 3) would be expected to be near unity. Note that $\phi<1$ (or $\phi>1$ ) indicates that the calculated $\left[\mathrm{NO}_{2}\right]$ is less (higher) than observed $\left[\mathrm{NO}_{2}\right]$ and that concentration levels of observed peroxy radicals (e.g., $\left[\mathrm{HO}_{2}\right]$ and $\left[\mathrm{RO}_{2}\right]$ ) are too low (high) to sustain PSS, implying a large deviation from the PSS. Note that there was no impact of data near sunrise and sunset $\left(\mathrm{SZA}>85^{\circ}\right)$ on the $\phi$ calculations and the linear regression due to lack of measurement parameters on a common time base over these periods. The mean PSS parameter $(\phi)$ and the slope of the best-fit line in the Fig. 3 were similar, except for FTCO (Table 3). The mean $\phi$ values ranged from 0.93 (FTMA) to 1.19 (BL) with the mean value of 1.08 for all data (Fig. 3a). Based on error propagation analysis using measurement uncertainties, the uncertainty $(1 \sigma)$ of the parameter $\phi$ is estimated to range from 21 to $22 \%$.

In general, $\mathrm{NO}_{2} / \mathrm{NO}$ ratios are near PSS, showing a strong correlation $\left(r^{2}=0.73\right)$ with the value of $\left\{k_{1}\left[\mathrm{O}_{3}\right]+k_{3}\left[\mathrm{HO}_{2}\right]+k_{4}\left[\mathrm{RO}_{2}\right]\right\} / J_{2}$. A slightly higher mean $\phi$ value (1.19) for BL was estimated, compared to those (1.06 and 0.93 ) for FTCO and FTMA. As the key components of $\mathrm{NO}-\mathrm{NO}_{2}$ partitioning, the concentrations of ozone and peroxy radicals for BL were up to a factor of 1.5 and 2.5 higher than those for FTCO and FTMA, respectively. Table 4 shows the contribution of ozone and peroxy radicals to the observed $\mathrm{NO}_{2} / \mathrm{NO}$ ratio, where the statistical values were calculated from the data sets with $\mathrm{SZA} \leq 85^{\circ}$. The ratios were controlled mainly by ozone levels (e.g., $61-71 \%$ contribution). 

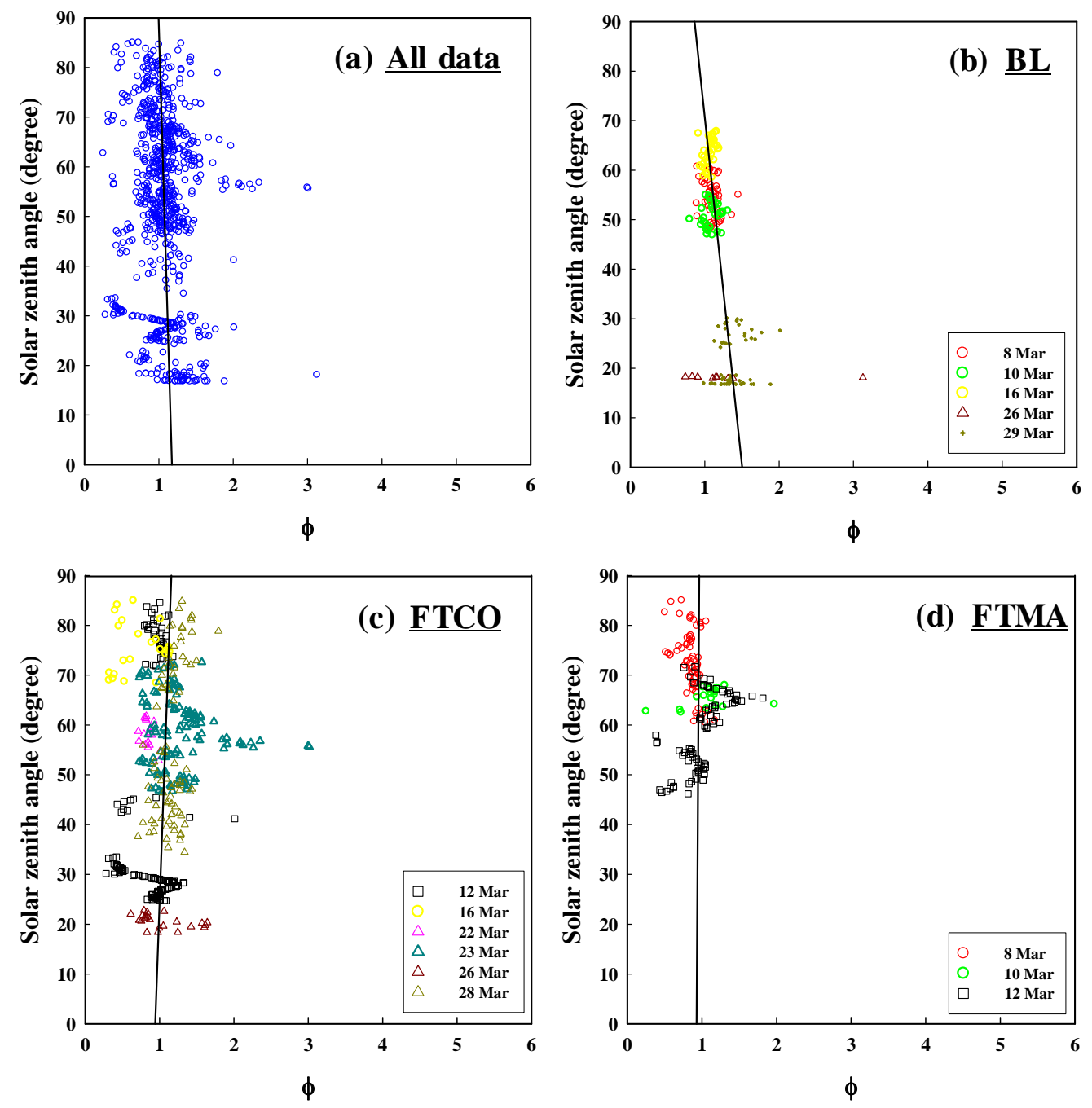

Fig. 5. Relation between solar zenith angle (SZA) and the PSS parameter $(\phi)$ for 3 air mass categories (all a, BL b, FTCO c, and FTMA d).

Table 4. Contribution of $\mathrm{O}_{3}$ and peroxy radicals to the $\mathrm{NO}_{2} / \mathrm{NO}$ ratios.

\begin{tabular}{ccc}
\hline $\begin{array}{c}\text { Air mass } \\
\text { category }\end{array}$ & $\left(k_{1}\left[\mathrm{O}_{3}\right]\right) / J_{2}{ }^{*}$ & $\left(k_{3}\left[\mathrm{HO}_{2}\right]+k_{4}\left[\mathrm{RO}_{2}\right]\right) / J_{2}{ }^{*}$ \\
\hline BL & $3.18 \pm 1.40(3.04)$ & $1.62 \pm 0.47(1.58)$ \\
& $66 \%$ & $34 \%$ \\
FTCO & $2.33 \pm 4.74(1.17)$ & $1.52 \pm 1.36(1.27)$ \\
& $61 \%$ & $39 \%$ \\
FTMA & $3.35 \pm 2.48(2.94)$ & $1.37 \pm 0.85(1.28)$ \\
& $71 \%$ & $29 \%$ \\
\hline
\end{tabular}

Values were calculated from the data set with $\mathrm{SZA} \leq 85^{\circ}$.

* The number in parenthesis represents a median value.
As noted above, the discrepancy between the observed $\left[\mathrm{NO}_{2}\right] /[\mathrm{NO}]$ ratios (denominator in Eq. 2) and calculated ratios (numerator in Eq. 2) was slightly different with air mass types. For instance, the discrepancy for BL was 12 to $28 \%$ higher than that for FTCO (t-test, P-value $=1.22 \times 10^{-6}$ ) and FTMA (P-value $\left.=8.90 \times 10^{-19}\right)$. In addition, the PSS value for each air mass is statistically different from unity ( $\mathrm{t}$ value $=10.83$ for BL, 3.28 for FTCO, and -3.40 for FTMA). In other words, the PSS values for the BL and FTCO were higher than unity, whereas that for FTMA was lower than unity. Interestingly, the marine atmosphere only showed value less than unity. As shown in Fig. 3, the PSS values in the lower altitude were somewhat higher than unity, whereas those in the higher altitude were lower than unity. One potential of this can be in part vertical iodine levels, which was indirectly supported by vertical $\mathrm{CH}_{3} \mathrm{I}$ profile showing slightly higher concentrations in the higher altitude (not shown here). The detailed discussion on this is given below. 

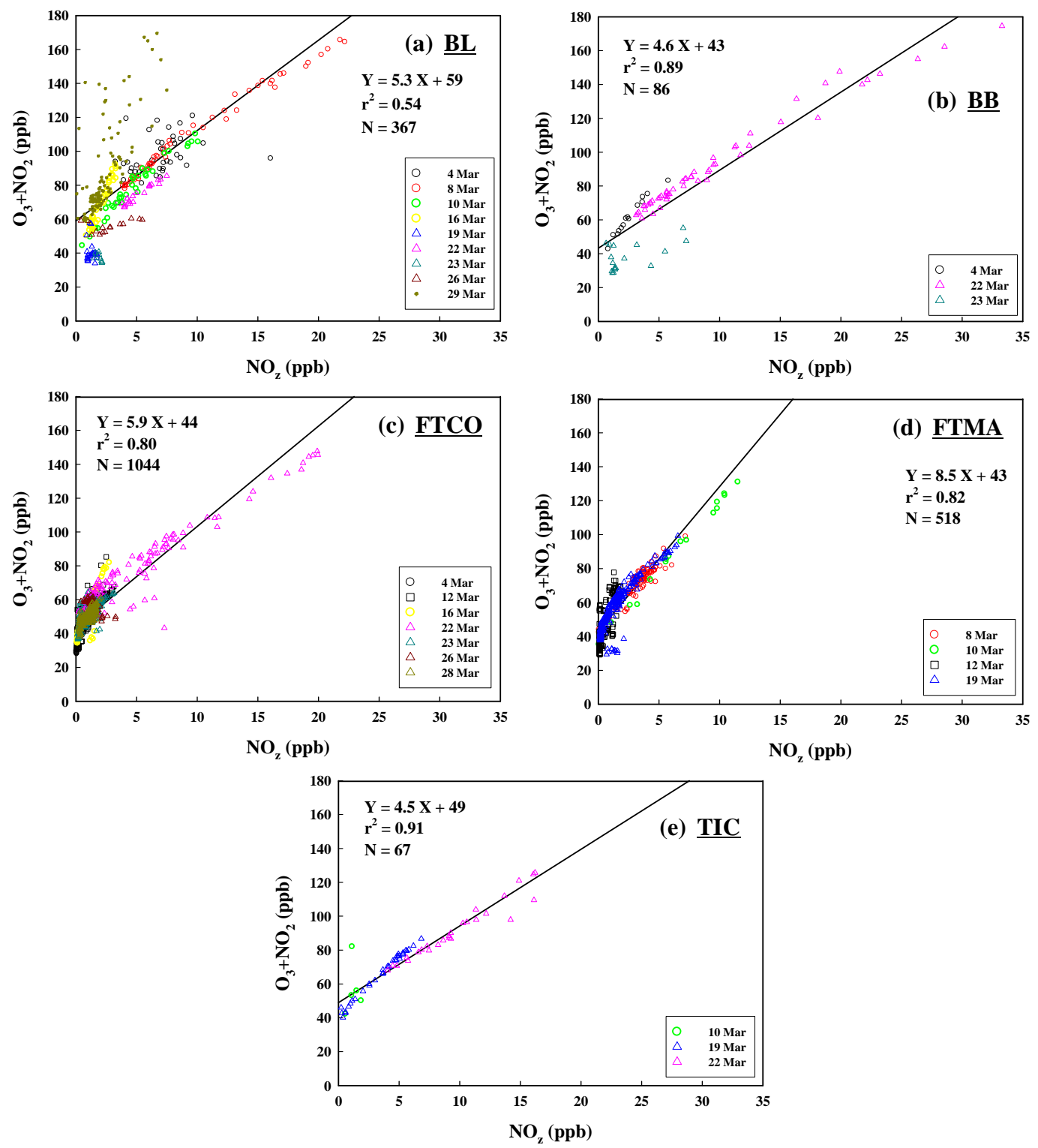

Fig. 6. Correlation between $\mathrm{O}_{3}+\mathrm{NO}_{2}$ and $\mathrm{NO}_{\mathrm{z}}$ for 5 air mass categories (BL a, BB b, FTCO c, FTMA d, and TIC e).

The discrepancy between the observed and calculated ratios can suggest the possibility of lack of current understanding of the tropospheric chemistry mechanism. The potential role of iodine chemistry in $\mathrm{NO}_{2} / \mathrm{NO}$ ratio change has been suggested based on field, model, and kinetic studies (Chameides and Davis, 1980; Davis et al., 1996; Knight and Crowley, 2001). Recently, significant impact of iodine chemistry (e.g., reaction of IO with $\mathrm{NO}$ producing $\mathrm{NO}_{2}$ ) on the observed $\mathrm{NO}_{2} / \mathrm{NO}$ ratio has been reported for the field study at Rishiri island, Japan (Kanaya et al., 2002, 2007). For the source of IO radicals, the photolysis of iodocarbons $\left(\mathrm{CH}_{3} \mathrm{I}\right.$, $\mathrm{CH}_{2} \mathrm{I}_{2}, \mathrm{C}_{2} \mathrm{H}_{5} \mathrm{I}$, and $\mathrm{CH}_{2} \mathrm{ICl}$ ), followed by the reaction of $\mathrm{O}_{3}$ and I can produce the IO radical. It has been reported that the source strength for iodocarbons such as $\mathrm{CH}_{2} \mathrm{I}_{2}, \mathrm{C}_{2} \mathrm{H}_{5} \mathrm{I}$, and
$\mathrm{CH}_{2} \mathrm{ICl}$ could possibly exceed that for $\mathrm{CH}_{3} \mathrm{I}$ (Davis et al., 1996 and references therein). In high biological productivity regions, $\mathrm{CH}_{3} \mathrm{I}$ concentration in the coastal air reached as high as 43 pptv (Oram and Penkett, 1994). When the iodine chemistry scenario is applied to this study, the IO mixing ratio required to reproduce the PSS of $\mathrm{NO}-\mathrm{NO}_{2}$ system (i.e., increase of $\phi$ from 0.93 to 1.0 ) were estimated to be $0.8 \mathrm{pptv}$ for FTMA on average. Similar ranges of IO levels (e.g., 0.3 pptv at Cape Grim and 0.5-7 pptv at Mace Head) have been observed in the marine atmosphere (McFiggans, et al., 2000; Allan et al., 2000; Saiz-Lopez and Plane, 2004). Based on the analysis of air mass back trajectory for FTMA (not shown here), the air mass originated from the Pacific coast of Mexico, which is a region of upwelling of nutrient-rich 
seawater (Bulgakov et al., 2005). In the tropical region, there is the strong vertical mixing of $\mathrm{CH}_{3} \mathrm{I}$ from boundary layer to free troposphere (Davis et al., 1996). Thus, this suggests the potential role of halogen chemistry in $\mathrm{NO}_{2} / \mathrm{NO}$ ratio shift for the marine atmosphere.

It appears that there is slight trend in the PSS parameter $\phi$ in terms of altitude (above ground level and a.s.l.) (Fig. 4). With increasing altitudes, the proportion of $\phi$ values less than 1 generally increases, especially for FTCO and FTMA. In addition, the relation between $\phi$ and SZA is shown in Fig. 5. There was no clear trend between these two parameters. For the BL, the $\phi$ values were almost constant regardless of the SZA. The $\phi$ values for the FTCO showed large variation both at the ranges from 25 to $30^{\circ} \mathrm{SZA}$ and from 70 to $85^{\circ} \mathrm{SZA}$, whereas they were almost uniform in between. However, $\phi$ values for FTMA varied significantly but not systematically with SZA.

According to a previous study of the PSS analysis of NO$\mathrm{NO}_{2}$ system (Crawford et al., 1996), the PSS parameter $(\phi)$ was reported to range from 0.30 to 0.75 , estimated for several airborne sampling campaigns such as PEM-West A, CITE-3, ABLE-3B, CITE-2, and TRACE-A. From these campaigns, most $\phi$ values were close to 0.71 , but that for PEM-West A (0.30) was significantly lower in comparison. The cause for the significantly large deviation from the PSS in PEMWest A was suggested to be interference in the $\mathrm{NO}_{2}$ measurement and this possibility stimulated improvements to the measurement technique during PEM-Tropics A (Bradshaw et al., 1999).

\subsection{Ozone Production Efficiency (OPE)}

Photochemical oxidation of $\mathrm{NO}_{\mathrm{x}}$ and its oxidation products were interrelated with $\mathrm{O}_{3}$ formation during the daytime. The OPE, which is the number of $\mathrm{O}_{3}$ molecules produced per molecule of $\mathrm{NO}_{\mathrm{x}}$ oxidized (Kleinman et al., 2002 and references therein), was estimated using the linear regression slope between $\mathrm{O}_{3}$ and oxidized $\mathrm{NO}_{x}$ products $\left(\mathrm{NO}_{\mathrm{z}}=\mathrm{NO}_{\mathrm{y}}-\mathrm{NO}_{\mathrm{x}}\right)$. Figure 6 shows the correlation between odd oxygen $\left(\mathrm{O}_{3}+\mathrm{NO}_{2}\right)$ and $\mathrm{NO}_{z}$, with OPEs for the 5 air mass categories in this field campaign ranging from 4.5 (TIC) to 8.5 (FTMA), indicating progressively more photochemically aged air masses. In general, higher efficiencies (5.98.5) were observed in FTCO and FTMA, which can be supported in part by lower $\mathrm{NO}_{2} / \mathrm{NO}$ ratios, whereas lower OPEs (4.5-4.6) were found in TIC and BB. To some extent, these lower OPEs in TIC and BB might result from high NO levels $(0.5-0.7 \mathrm{ppbv})$ that are enough to cause enhancements in $\mathrm{OH}$ levels and thus shorten $\mathrm{NO}_{\mathrm{x}}$ lifetime, and from higher organic peroxy radicals leading to additional $\mathrm{NO}_{\mathrm{x}}$ loss through organic nitrate formation. The OPEs in this field campaign were within the OPE ranges for the urban and rural atmosphere (Rickard et al., 2002 and references therein).

\section{Summary and conclusions}

Previous studies testing the NO- $\mathrm{NO}_{2}$ cyclic system were conducted in urban and remote areas using observations of $\mathrm{O}_{3}$ (R1) and/or peroxy radicals (R3-R4). These earlier studies used the concentrations of model-predicted peroxy radicals test the PSS for $\mathrm{NO}-\mathrm{NO}_{2}$ cyclic system and indicated that the peroxy radicals were not sufficient to explain the observed $\mathrm{NO}_{2} / \mathrm{NO}$ ratio. In addition, the model-predicted $\mathrm{NO}_{2}$ levels in previous studies were reported to be somewhat lower than observations. In this study, we analyzed the $\mathrm{NO}-\mathrm{NO}_{2}$ system in different chemical regimes/air masses based on observations of reactive nitrogen species and peroxy radicals measured during the intensive field campaign of MIRAGE-Mex (4 March to 29 March 2006). For the PSS analysis, the air mass was categorized into 5 groups such as BL, BB, FTCO, FTMA, and TIC.

In general, $\mathrm{NO}_{2} / \mathrm{NO}$ ratios seem to be near PSS. In addition, the PSS value $(\phi)$ for each air mass is statistically different from unity. In other words, the PSS values for the BL and FTCO were higher than unity, whereas that for FTMA was lower than unity. Overall, there was no distinct PSS dependence on altitude and SZA. The mean $\mathrm{NO}_{\mathrm{x}} / \mathrm{NO}_{\mathrm{y}}$ ratios varied from 0.15 (FTMA) to 0.38 (BL), indicating less photochemically aged air masses of polluted plume exiting Mexico City Metropolitan Area. Ozone production efficiencies ranged from 4.5 (TIC) to 8.5 (FTMA). The potential role of halogen chemistry in $\mathrm{NO}_{2} / \mathrm{NO}$ ratio shift (i.e., lowering the PSS parameter, $\phi$ ) in the marine atmosphere (FTMA case) can not be excluded according to our simple estimated IO concentration for the conversion of $\mathrm{NO}$ to $\mathrm{NO}_{2}$ by IO.

Acknowledgements. ZHS was financially supported by the Climate Environment System Research Center sponsored by the SRC program of Korea Science and Engineering Foundation. The authors thank John Holloway for providing $\mathrm{SO}_{2}$ data, Don Blake for $\mathrm{C}_{2} \mathrm{Cl}_{4}$ data, and Paul Wennberg and John Crounse for providing the $\mathrm{HCN}$ data used in this analysis; measurements of $\mathrm{HCN}$ supported by NASA (NNG06GB32G). The National Center for Atmospheric Research is operated by the University Corporation for Atmospheric Research under the sponsorship of the National Science Foundation.

Edited by: L. Molina

\section{References}

Allan, B., McFiggans, G., and Plane, J.: Observations of iodine monoxide in the remote marine boundary layer, J. Geophys. Res., 105(D11), 14 363-14369, 2000.

Bradshaw, J., Davis, D., Crawford, J., Chen, G., Shetter, R., Müller, M., Gregory, G., Sachse, G., Blake, D., Heikes, B., Singh, H., Mastromarino, J., and Sandholm, S.: Photofragmentation twophoton laser-induced fluorescence detection of $\mathrm{NO}_{2}$ and $\mathrm{NO}$ : Comparison of measurements with model results based on airborne observations during PEM-Tropics A, Geophys. Res. Lett., 26(4), 471-474, doi:10.1029/1999GL900015, 1999. 
Bulgakow, S. N., Bulgakow, N. P., Mikhailova, E. N., and Shapiro, N. B.: Generation of upwelling near the Pacific coast of Mexico, Phys. Oceanol., 15, 27-36, 2005.

Cantrell, C. A., Edwards, G. D., Stephens, S., Mauldin, L., Kosciuch, E., Zondlo, M., and Eisele, F.: Peroxy radical observations using chemical ionization mass spectrometry during TOPSE, J. Geophys. Res., 108(D6), 8371, doi:10.1029/2002JD002715, 2003.

Cantrell, C. A., Shetter, R. E., Calvert, J. G., Eisele, F. L., Williams, E., Baumann, K., Brune, W. H., Stevens, P. S., and Mather, J. H.: Peroxy radicals from photostationary state deviations and steady state calculations during the Tropospheric $\mathrm{OH}$ Photochemistry Experiment at Idaho Hill, Colorado, 1993, J. Geophys. Res., 102(D5), 6369-6378, doi:10.1029/96JD01703, 1997.

Carroll, M. A., Ridley, B. A., Montzka, D. D., Hübler, G., Walega, J. G., Norton, R. B., Huebert, B. J., and Grahek, F. E.: Measurements of nitric oxide and nitrogen dioxide during the Mauna Loa Observatory Photochemistry Experiment, J. Geophys. Res., 97(D10), 10361-10374, 1992.

Chameides, W. L. and Davis, D. D.: Iodine: its possible role in tropospheric chemistry, J. Geophys. Res., 85(12), 7383-7398, 1980.

Crawford, J., Davis, D., Chen, G., Bradshaw, J., Sandholm, S., Gregory, G., Sachse, G., Anderson, B., Collins, J., Blake, D., Singh, H., Heikes, B., Talbot, R., and Rodriguez, J.: Photostationary state analysis of the $\mathrm{NO}_{2}$ - $\mathrm{NO}$ system based on airborne observations from the western and central North Pacific, J. Geophys. Res., 101(D1), 2053-2072, doi:10.1029/95JD02201, 1996.

Davis, D., Crawford, J., Liu, S., McKeen, S., Bandy, A., Thornton, D., Rowland, F., and Blake, D.: Potential impact of iodine on tropospheric levels of ozone and other critical oxidants, J. Geophys. Res., 101(D1), 2135-2147, doi:10.1029/95JD02727, 1996.

Gregory, G. L., Fuelberg, H. E., Longmore, S. P., Anderson, B. E., Collins, J. E., and Blake, D. R.: Chemical characteristics of tropospheric air over the tropical South Atlantic Ocean: Relationship to trajectory history, J. Geophys. Res., 101(D19), 23 95723 972, doi:10.1029/96JD01160, 1996.

Kanaya, Y., Tanimoto, H., Matsumoto, J., Furutani, H., Hashimoto, S., Komazaki, Y., Tanaka, S., Yokouchi, Y., Kato, S., Kajii, Y., and Akimoto, $\mathrm{H}$.: Diurnal variations in $\mathrm{H}_{2} \mathrm{O}_{2}, \mathrm{O}_{3}, \mathrm{PAN}, \mathrm{HNO}_{3}$ and aldehyde concentrations and $\mathrm{NO} / \mathrm{NO}_{2}$ ratios at Rishiri Island, Japan: Potential influence from iodine chemistry, Sci. Total Environ., 376, 185-197, 2007.

Kanaya, Y., Yokouchi, Y., Matsumoto, J., Nakamura, K., Kato, S., Tanimoto, H., Furutani, H., Toyota, K., and Akimoto, H.: Implications of iodine chemistry for daytime $\mathrm{HO}_{2}$ levels at Rishiri Island, Geophys. Res. Lett., 29, 1212, doi.:10.1029/2001GL014061, 2002.

Kleinman, L. I., Daum, P. H., Lee, Y. -N., Nunnermacker, L. J., Springston, S. R., Weinstein-Lloyd, J., and Rudolph, J.: Ozone production efficiency in an urban area, J. Geophys. Res., 107(D23), 4733, doi:10.1029/2002JD002529, 2002.

Knight, G. P. and Crowley, J. N.: The reactions of IO with $\mathrm{HO}_{2}$, $\mathrm{NO}$ and $\mathrm{CH}_{3} \mathrm{SCH}_{3}$ : flow tube studies of kinetics and product formation, Phys. Chem. Chem. Phys., 3(3) 393-401, 2001.

Koike, M., Kondo, Y., Kita, K., et al.: Export of anthropogenic reactive nitrogen and sulfur compounds from the East Asia region in spring, J. Geophys. Res., 108(D20), 8789, doi:10.1029/2002JD003284, 2003.

Li, Q., Jacob, D. J., Bey, I., Yantosca, Y. M., Zhao, Y., Kondo, Y., and Notholt, J.: Atmospheric hydrogen cyanide (HCN): biomass burning source, ocean sink?, Geophys. Res. Lett., 27(3), 357$360,2000$.

Maloney, J. C., Fuelberg, H. E., Avery, M. A., Crawford, J. H., Blake, D. R., Heikes, B. G., Sachse, G. W., Sandholm, S. T., Singh, H., and Talbot, R. W.: Chemical characteristics of air from different source regions during the second Pacific Exploratory Mission in the Tropics (PEM-Tropics B), J. Geophys. Res., 106(D23), 32 609-32 626, doi:10.1029/2001JD900100, 2001.

McFiggans, G., Plane, J., Allan, B., and Carpenter, L.: A modeling study of iodine chemistry in the marine boundary layer, J. Geophys. Res., 105(D11), 14 371-14385, 2000.

Nunnermacker, L. J., Kleinman, L. I., Imre, D., Daum, P. H., Lee, Y.-N., Lee, J. H., Springston, S. R., Newman, L., and Gillani, N.: $\mathrm{NO}_{y}$ lifetimes and $\mathrm{O}_{3}$ production efficiencies in urban and power plant plumes: Analysis of field data, J. Geophys. Res., 105(D7), 9165-9176, doi:10.1029/1999JD900753, 2000.

Oram, D. E. and Penkett, S.A.: Observations in eastern England of elevated methyl iodide concentrations in air of Atlantic origin, Atmos. Environ., 28, 1159-1174, 1994.

Raga, G. and Raga, A.: On the formation of an elevated ozone peak in Mexico City, Atmos. Environ., 34, 4097-4102, 2000.

Raga, G., Baumgardner, D., Castro, T., Martínez-Arroyo, A., and Navarro-González, R.: Mexico City air quality: a qualitative review of gas and aerosol measurements (1960-2000), Atmos. Environ., 35, 4041-4058, 2001.

Ridley, B. A., Madronich, S., Chatfield, R. B., Walega, J. G., Shetter, R. E., Carroll, M. A., and Montzka, D. D.: Measurements and model simulations of the photostationary state during MLOPEX: Implications for radical concentrations and ozone production and loss rates, J. Geophys. Res., 97, 10375-10388, 1992.

Rickard, A. R., Salisbury, G., Monks, P. S., Lewis, A. C., Baugitte, S., Bandy, B. J., Clemitshaw, K. C., and Penkett S. A.: Comparison of measured ozone production efficiencies in the marine boundary layer at two European coastal sites under different pollution regimes, J. Atmos. Chem., 43, 107-134, 2002.

Saiz-Lopez, A. and Plane, J. M. C.: Novel iodine chemistry in the marine boundary layer, Geophys. Res. Lett., 31, L04112, doi:10.1029/2003GL019215, 2004.

Sander, S. P., Friedl, R. R., Golden, D. M., Kurylo, M. J., Moortgat, G. K., Ravishankara, A. R., Kolb, C. E., Molina, M. J., and Finlayson-Pitts, B. J.: Chemical kinetics and photochemical data for use in stratospheric modeling, Jet Propulsion Laboratory Publication 02-25, Jet Propulsion Laboratory, Pasadena, California, 2002.

Shetter, R. E., Cinquini, L., Lefer, B. L., Hall, S. R., and Madronich, S.: Comparison of airborne measured and calculated spectral actinic flux and derived photolysis frequencies during the PEM Tropics B mission, J. Geophys. Res., 108(D2), 8234, doi:10.1029/2001JD001320, 2003.

Soltic, P. and Weilenmann, M.: $\mathrm{NO}_{2} / \mathrm{NO}$ emissions of gasoline passenger cars and light-duty trucks with Euro-2 emission standard, Atmos. Environ., 37, 5207-5216, 2003.

Takegawa, N., Kondo, Y., Koike, M., et al.: Removal of $\mathrm{NO}_{\mathrm{x}}$ and $\mathrm{NO}_{\mathrm{y}}$ in Asian outflow plumes: Aircraft measurements over the western Pacific in January 2002, J. Geophys. Res., 109, D23S04, doi:10.1029/2004JD004866, 2004.

Tie, X., Madronich, S., Li, G. H., Ying, Z., Zhang, R., Garcia, A. R., Lee-Taylor, J., and Liu, Y.: Characterizations of chemical 
oxidants in Mexico City: A regional chemical dynamical model (WRF-Chem) study, Atmos. Environ., 41, 1989-2008, 2007.

Weinheimer, A. J., Montzka, D. D., Campos, T. L., et al.: Comparison between DC-8 and ER-2 species measurements in the tropical middle troposphere: $\mathrm{NO}, \mathrm{NO}_{\mathrm{y}}, \mathrm{O}_{3}, \mathrm{CO}_{2}, \mathrm{CH}_{4}$, and $\mathrm{N}_{2} \mathrm{O}$, J. Geophys. Res., 103(D17), 22 087-22 096, 1998.
Yokelson, R. J., Urbanski, S. P., Atlas, E. L., Toohey, D. W., Alvarado, E. C., Crounse, J. D., Wennberg, P. O., Fisher, M. E., Wold, C. E., Campos, T. L., Adachi, K., Buseck, P. R., and Hao, W. M.: Emissions from forest fires near Mexico City, Atmos. Chem. Phys., 7, 5569-5584, 2007,

http://www.atmos-chem-phys.net/7/5569/2007/. 